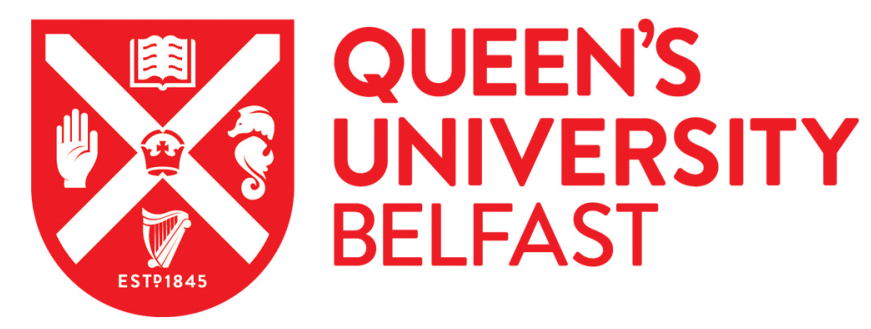

\title{
Childhood in transition: growing up in 'post-conflict' Northern Ireland
}

McAlister, S., Scraton, P., \& Haydon, D. (2014). Childhood in transition: growing up in 'post-conflict' Northern Ireland. Children's Geographies, 12(3), 297-311. https://doi.org/10.1080/14733285.2014.888399

\author{
Published in: \\ Children's Geographies
}

\section{Document Version:}

Peer reviewed version

\section{Queen's University Belfast - Research Portal:}

Link to publication record in Queen's University Belfast Research Portal

\section{Publisher rights}

(C) 2014 Taylor \& Francis

This is an Accepted Manuscript of an article published by Taylor \& Francis in Children's Geographies on 21 February 2014, available online: http://www.tandfonline.com/doi/abs/10.1080/14733285.2014.888399.

\section{General rights}

Copyright for the publications made accessible via the Queen's University Belfast Research Portal is retained by the author(s) and / or other copyright owners and it is a condition of accessing these publications that users recognise and abide by the legal requirements associated with these rights.

Take down policy

The Research Portal is Queen's institutional repository that provides access to Queen's research output. Every effort has been made to ensure that content in the Research Portal does not infringe any person's rights, or applicable UK laws. If you discover content in the Research Portal that you believe breaches copyright or violates any law, please contact openaccess@qub.ac.uk. 


\title{
Childhood in transition: growing up in 'post conflict' Northern Ireland
}

\begin{abstract}
Northern Ireland is in the early stages of transition from conflict, but progress is regularly affected by political and public discontent. A divided landscape, segregated and underresourced communities are enduring legacies of 'the Conflict'. ${ }^{1}$ Yet the political will to tackle social and community division, consult with and support communities has been lacking. Grounded in six communities most affected by poverty and the Conflict this article illustrates the difficulties, tensions and contradictions experienced during transition and how, in the process of 'change', children and young people have been silenced, marginalised and demonised.
\end{abstract}

Keywords: Northern Ireland; conflict; community; informal control; identity.

\section{Introduction: children, communities and conflict}

Emerging from its most recent and prolonged period of conflict, Northern Ireland is in a period of transition defined by some as neither peace nor war (MacGinty, Muldoon, and Ferguson 2007). While the Conflict touched the lives of many, its impact was not experienced equally. Young men living in areas of economic deprivation were disproportionately at risk of 'troubles-related death' (Fay, Morrison, and Smyth 1998), with 35.5 per cent of those killed under the age of 25 (Smyth 1998, 3.2, Table 2). Between 1969 and March 1998 an estimated 257 children under the age of 18 died as a consequence of the Conflict (ibid., Table 1). Children and young people endured additional violence in the form of paramilitary attacks, ${ }^{2}$ with young men in their twenties the main victims (Knox 2002, 176).

Aside from death and injury, the social effects of the Conflict have been far reaching, generating a lasting impact. The social and spatial landscape of Northern Ireland has been affected profoundly by displacement and population movement (Community Relations

\footnotetext{
${ }^{1}$ The term 'the Conflict' is used to refer to the period of armed conflict involving state and non-state groups between 1969 and 1998 when the Belfast/ Good Friday Agreement, signed by most political parties in Northern Ireland, the British and Irish Governments, established a commitment to democratic and peaceful means of resolving political issues.

${ }^{2}$ Paramilitary groups often acted as agents of informal control, policing communities through public warnings, acts of humiliation, exiling, beatings and shootings.
} 
Council, 1971, cited in Byrne et al 2006, 16). Fear, insecurity and forced exiling have consolidated a deeply segregated society through which the search for safety and solidarity has resulted in large proportions of the two main ethno-national groups (Catholic/ Nationalist/ Republican and Protestant/ Unionist/ Loyalist) living, being schooled and socialising separately. Displacement and relocation intensified with increased levels of violence. A 2003 survey revealed that 54,000 households had relocated because of intimidation, threats or harassment (Hillyard, Rolston, and Tomlinson 2005, 6). Such movements established clearly demarcated spatial divisions within towns and cities, with residential segregation most pronounced in working class areas. It is reported, for example, that 91 per cent of housing executive estates (public housing) in Belfast comprise of more than 80 per cent of one community/ cultural group (Shuttleworth and Lloyd 2007). Further, 66 per cent of Northern Ireland's population live in areas where most neighbours share the same religious background (Shirlow 2003).

Hamilton et al. (2008, 20-21) note that quantifying segregation tends to mask geographical differences, over-simplifying it as a working class issue and implying greater physical distance from 'the other' community than is the reality. In some areas single identity communities are located close to each other, or alongside mixed-identity middle class areas (Boal 1982). Visible illustrations of the spatial division of the two main ethno-national groups include murals, flags, painted curbstones and 'peacewalls' 3 . There is no indication that residential segregation has diminished significantly since the signing of the 1998 Good Friday/ Belfast Agreement (Shuttleworth and Lloyd 2008). Indeed, the number and height of peacewalls have increased (McDonald 2009).

Further demonstrating the pervasiveness of community divisions, 94 per cent of the school-aged population attend segregated education in de facto Catholic or Protestant nursery, primary or post-primary schools (DENI 2008, 2). 'Basic daily routines' such as the use of social space, sports played and supported, festivals and cultural events attended, and choice of newspaper, 'are structured by the dominant sectarian divisions of Northern Irish society’ (Hamilton et al. 2008, 11). Through fear, tradition or habit, exclusive places and practices have persisted over time, resulting in 'mutual avoidance' (Larsen 1982, cited in

\footnotetext{
${ }^{3}$ A 'peacewall'/ 'peaceline' is a barrier (usually a wall, gate or fence) separating a Catholic/ Nationalist community and a Protestant/ Unionist community.
} 
Cohen 2010, 56). Ultimately, the 'social political and cultural distance between communities' has been sustained through physical separation (Shirlow and Murtagh 2006, 58).

The consequences of segregation are evident. Shirlow's survey of 18-25 year olds in twelve estates separated by peace walls in Belfast, for example, reveals that 68 per cent had never had 'a meaningful conversation' with a person from 'the other community' (Brown 2002). Reviewing survey findings, Jarman $(2005,4)$ estimates that more than one in four young people experienced sectarian abuse or harassment in the previous year. Children and young people continue to experience sectarianism as part of their daily lives - to and from the journey to school, in town centres, when venturing outside 'their' community boundary. Fearing sectarian attack, some young people consider themselves imprisoned within their neighbourhoods (McAlister, Scraton, and Haydon 2009).

Research reveals the localised impacts of the legacy of the Conflict. For example, leisure facilities and other services in predominantly Catholic or Protestant communities are not accessed by children and young people outside the community in North Belfast (Byrne, Conway and Ostermeyer 2005) or specific neighbourhoods in Belfast and Derry ( Hansson 2005). Some young people refuse to attend colleges or training courses in particular areas because of their location and perceived identity (Hamilton et al. 2008).

The 2011 Young Life and Times survey of 16-year olds across Northern Ireland indicates that 'there has been an increase in cross-community contact over recent years' with cross-community friendship more common in 2011 than reported in the 2003 survey, although 22 per cent reported they had no friends from the other main religious community (Devine and Robinson 2012). In the 2012 survey, six out of ten respondents considered leisure centres, parks and libraries 'shared and open' to both Catholics and Protestants but 45 per cent said there were no facilities in their area where they could meet with people of a different religion (Devine, 2013). Inevitably, lack of contact and mistrust prevent children and young people learning about the other's culture.

\section{Segregation, sectarianism and identity}

The impact of segregation on the development of children's identity in Northern Ireland has been the focus of research drawing on social psychological theories (e.g. Cairns 1987; Gallagher and Cairns 2011; Trew 1992). Employing primarily quantitative, 
experimental methods with school-based samples, studies have focused on the age-related development of attitudes and understandings about national identity, particularly children's understand of difference, 'preference' for their own cultural group and prejudice towards 'the other’. Social Identity Theory (SIT), for example, suggests that identity is shaped through group belonging. It proposes that comparison with 'other' groups strengthens positive 'ingroup’ identity (Tajfel and Turner 1986). In conflict-affected and divided societies, strong ‘in-group’ identification has been associated with ‘out-group’ prejudice (see Trew 2004).

Social Identity Development Theory (SIDT) suggests that, as children identify more with the 'in-group', they adopt negative attitudes and stereotypes about the 'out-group' (Gallagher and Cairns 2011). This is influenced by the degree to which children internalise the prejudices of the 'in-group’ and feel threatened by the 'out-group’ (Barrett and Oppenheimer 2011). The relationships between strength of national identity, 'out-group’ attitudes and perceived threats to identity are important in a society in transition from conflict where ethno-national identities are dominant. However, Brewer $(1999,431)$ questions the implication of a 'negative reciprocal relationship between ingroup and outgroup attitudes'. She notes that a strong positive attitude to one's own group does not always equate with prejudice towards 'out-groups'. Indeed, she suggests that some show indifference to the 'outgroup' or that their feelings of 'superiority' manifest in avoidance rather than conflict. In the context of Northern Ireland, some children and young people are so 'cocooned' in segregated communities that 'the other community' has no relevance to them (see Roche 2008).

In studies of children's 'intergroup’ attitudes and national identities, the research setting and highly structured methods of data collection can limit opportunities for personal explanations, conceal the complexities of children's and young people's lives, and limit the focus of analysis to pre-determined themes (see Connolly and Healy 2003), locating attitudes and beliefs in individual psycho-social development. In contrast, critical analysis takes the socioeconomic and political contexts of children's and young people's lives as its starting point. Recognising that identity is formed and re-formed through interpersonal relationships and interactions in social institutions, it examines the routine processes and activities of children's everyday lives - those contexts, events and processes that shape and delimit their experiences (see Shirlow 2003). 
White and Wyn $(2008,191)$ state that identity 'is always contingent upon immediate social circumstance, the weight of historical factors, and the agency of young people themselves', emphasising the significance of listening to children's and young people's personal accounts. This is central to understanding their beliefs, experiences and responses to the Conflict, segregation, sectarianism and identity. Our research indicates that the social, cultural and political contexts of children's and young people's lives play a significant role in their sense of cultural identity and their views of 'the other'. In examining how social and personal contexts inform attitudes, identities and experiences, the 'community' context is focal.

\section{Communities in conflict}

The relationship between poverty and conflict, and experiences of Conflict-related violence within particular communities,are complex. Hillyard et al. (2003) report a direct association between experiences of the Conflict and poor socio-economic circumstances. They found that those areas that had endured higher levels of conflict-related violence had also experienced greater poverty. Violence, death and injury were concentrated in the poorest communities, defined by the prevalence of ill-health, limited educational and employment opportunities, lower provision of services and less economic investment (Save the Children, 2007). Noting that poverty does not cause conflict, Horgan $(2011,456)$ maintains that 'conflict feeds on poverty while undermining the potential for those living in it to escape it'.

Despite their difficult histories, communities are often galvanised and strengthened through challenging conflict and segregation (Leonard 2004; Smyth 2000). Cattell (2001) also notes that strong perceptions and experiences of inequality can be a uniting and/or empowering force in areas of deprivation. In some instances, communities separated by conflict are characterised by high levels of social cohesion, strong community identity and feelings of safety (Murtagh 2002). The withdrawal of services from marginalised communities has stimulated community support and infrastructure as a necessity (McAlister, Scraton, and Haydon 2009). Leonard's (2004, 931) research in a high conflict area of Belfast found 'strong community networks and a self-help ethos'. She explains this as a consequence of the community's experiences during the Conflict, when economic and social disadvantage stemmed from 'political discrimination and the suppression of identity' (ibid.). 
Cohen (2010) notes that 'community' is relational, implying both similarity and difference. It is constituted and experienced as shared among community members, distinguishing them from other communities. However, Suttles $(1972,51)$ notes that neighbourhood identities are constructed in a 'contrastive structure', with 'relative differences' more significant than shared characteristics among those within the same neighbourhood. This is relevant in Northern Ireland given that the only commonality shared within a community may be religious background (i.e. some may not identify as Unionist or Nationalist, or as British or Irish, but their religious inheritance and socialisation define their cultural and political identity). Given that 'place is standing for a set of cultural characteristics', it 'says something not only about where you live or come from but who you are' (Crang 1998, 103). In Northern Ireland, the physical and symbolic marking of community space is a defining, visual message of community and cultural identity. While communities can be places of support, belonging and safety, they can also signify hostility, fear and exclusion.

\section{Progress and political context}

Signed in 1998 the Good Friday/ Belfast Agreement signalled the potential for 'normalisation' in a jurisdiction steeped in civil and political violence. While setbacks occurred, the establishment of a devolved administration and shared political power, the renaming and restructuring of the police force and a review of criminal justice, symbolised moves toward enacting the core principles of the Agreement - transparency, equality, rights and social justice. Given a significant reduction in sectarian violence and the opening of public space, the night-time economy expanded, tourism grew and, until the recent economic crisis, there were visible signs of economic rejuvenation. Commenting on Belfast and the depoliticisation of space, Murtagh $(2008,9)$ notes:

For a city whose recent imagery has been built on violence, peace lines and fear, the formation of low risk, glitzy and speculator investment sites has been a vital strategy in normalization and place marketing.

Yet persistent low level and localised violence continues, particularly in interface areas. There is recognition that 'post-conflict' Belfast is a 'twin speed city’ (Murtagh 2008), with two dimensions - 'Consumerist Belfast' and 'Troubles Belfast' (O’Dowd and 
Komarova 2010, 10). Some areas and communities have benefited from the peace dividend but 'those without resources are increasingly corralled in "sink" estates, stratified by poverty, segregation and fear' (Murtagh 2008, 4), illustrating the enduring relationship between poverty and conflict. Levels of fear, resentment and sectarianism become more apparent when violence is most pronounced, for example, during clashes at key cultural events or through the activities of dissident paramilitaries. While there is an acceptance that 'latent violence can suddenly become manifest' (Nolan 2012, 42), such incidents are regularly decontextualised by the media and downplayed by politicians as the behaviour of a few 'opportunists' or 'hangers on'. Alternatively, they are represented as 'mindless violence'.

Defined as an 'élite level’ political settlement (MacGinty, Muldoon and Ferguson 2007) based on a consociational framework (see Dixon 2004), the Good Friday/ Belfast Agreement has been criticised for focusing on accepting and managing difference with the primary aim of reducing violence. This and the outworkings of the peace process more generally have failed to address the structural divisions that maintain conflict and separatist identities (see Shirlow 2003). Protests about the regulation or removal of cultural symbols and events, combined with political wrangling over how to deal with and commemorate the past, sustain a climate of division, intolerance and simmering tension. Given this context, it is unsurprising that Northern Ireland has been described as experiencing 'cold peace' or 'peace-without-reconciliation', portrayed as a place 'stuck in a model that reinforces the traditional divisions' (Nolan 2012, 16). Northern Ireland's first peace monitoring report also noted the fragility of peace and the vulnerability of working class young men to involvement in violence (Nolan 2012).

\section{Research context and methods}

While the external face of formal politics has promoted 'peace' and the significance of Northern Ireland as an exemplar of conflict transformation, there is a strong sense in the child and youth sector that this representation masks the reality of sectarian politics and the continuing impact on children and their families of living in a divided society (Kilkelly et al, 2004). The research on which this paper is founded arose from the identified need to explore in depth children's and young people's experiences of political and economic marginalisation in the context of the legacy of conflict. The research was conducted in communities 
profoundly affected by poverty, sectarianism and violence during 2008, a decade after the signing of the Good Friday/ Belfast Agreement.

Qualitative research (combining interviews, focus groups and observation) was conducted in six communities, one in each of Northern Ireland's six counties. Each community had endured relatively high levels of poverty combined with Conflict-related violence including bereavement, internment and/or imprisonment. The communities were both urban and rural. Five were predominantly Catholic/ Nationalist/ Republican or Protestant/ Unionist/ Loyalist. One was 'mixed', although its internal boundaries were clearly demarcated and there was virtually no integration.

In piloting the research framework, preliminary focus groups were held with 25 young people in four locations across Northern Ireland. Their involvement at the formative stage of the research contributed significantly to the authenticity of the research as child/ young people centred. The researchers interviewed 65 'community representatives' to establish specific historical context and build trust in communities wary of outsiders. These representatives included community members/ residents and community workers. The latter, some of whom lived in the community, were interviewed in their role as teachers and afterschool workers, community development workers, youth workers, children and family service workers, police. Following these 'scene-setting' interviews, focus groups and interviews were conducted with 196 children and young people aged 8-25, accessed primarily through community-based schemes and youth workers. Given the controversial and often personal research topics (relationships; education; employment; place and identity; segregation and sectarianism; violence; community; policing; services and support), it was decided that accessing children and young people through schools would constrain both access and dialogue.

The qualitative research reflects the dynamics of 'personal/ familial' and 'social/ cultural' relations within economically marginalised and conflict-affected communities undergoing transition from conflict. Such dynamics are prescribed through the intervention of state agencies, particularly policing, social care, housing and schooling. As the research progressed, three key tensions emerged: expressions of insecurity and fear post-ceasefire; young people’s sectarian and violent behaviour; the marginalisation and silencing of children and young people within communities. What follows explores culture, identity and 
'belonging' as key priorities for children and young people, juxtaposed with adult community members' views about 'lack of policing' and weak social regulation.

\section{Communities in transition}

The six communities involved in the research included areas of relocation for families exiled from their homes elsewhere, residential locations for police and security forces, and recruitment sites for paramilitary groups. The communities had experienced relatively high numbers of deaths and injuries, and the volume of bombings, shootings and other attacks during the height of the Conflict had constantly disrupted everyday life. Some had been heavily fortified, with large police or army bases located nearby, and security forces had been a permanent feature on their streets.

Reflecting MacGinty, Muldoon, and Ferguson’s (2007, 2) claim of 'public disaffection with an élite level peace accord', the majority of community representatives interviewed considered that the Peace Agreement and devolved administration were distanced from the issues affecting communities. They stated that the histories of specific communities, and the profound difficulties they experienced, were unrecognised in political discussions or decisions about the future of Northern Ireland:

'With the likes of the Good Friday Agreement, nobody looked at what needed to be put in place in the long-term to support communities through this time of transition the focus was always about getting the Assembly going ...' (Community worker)

'There have been changes in Government but not on the ground. They don't care what's happening on the ground ... you can’t clear up the Conflict in a few years.' (Community member)

It was felt that progress at a political level had not been matched by progress within and between communities. Community representatives resented the rhetoric of peace as they attempted, often unsupported and with few resources, to address the legacy of the Conflict: historical under-investment; inadequate services to meet identified needs; material poverty; mental ill-health; trans-generational trauma; sporadic violence; isolation, fear and restricted movements (McAlister, Scraton, and Haydon 2009; Smyth et al. 2004). Anger was directed at 
politicians who proclaimed 'peace' but were disengaged from the reality of their constituents' lives:

'... sometimes I'd be sittin' watchin' the TV and I'd be standin' up goin' "You see you bastards, you don’t even know what it's like livin' on the streets. Youse are all just sittin' in your wee offices, all just conductin' all this shite. Live on the streets, know what it's like before ye say all this stuff”. They don’t know nothin' ... sure they're still doin' paramilitary beatings ... They're still doin' it, they're never goin' to stop”.' (Young person, aged 21 - her emphasis)

As Smyth (2004, 558-559) states, 'the disappointment of raised expectations of improvements in quality of life in communities worst affected by conflict can compromise support for the settlement'.

Perceptions about lack of progress were intensified by a growing sense of regression, uncertainty and instability:

'[the area] has improved in some ways but has deteriorated in others. There is more violence post-conflict. People don't feel safe in this community when they always did in the past.' (Community worker)

This was a commonly expressed view on both sides of the political divide. The perception of increased violence and a corresponding increase in fear and insecurity was palpable, despite a significant decline in paramilitary violence, informal punishment beatings and exiling.

\section{Policing and transition}

The decline in paramilitary regulation within communities, alongside the reduction in violence, has resulted in an increased presence of young people in public spaces. Rather than being viewed as 'progress', this was raised by community representatives as a concern across the six communities - reflecting a generic concern in Northern Ireland about the physical presence of young people 'on the streets' (McAlister, Scraton, and Haydon 2011). Sometimes combined with heavy drinking, young people occasionally were involved in violent behaviour. This informed community members’ views about lack of safety. They believed 
that loosening the grip of informal, paramilitary control had allowed the streets to be reclaimed by 'anti-social' and 'threatening' children and young people.

Despite identifying the negative impact of violence and paramilitary regulation when explaining the history of their areas, community members discussing current concerns often addressed the past with nostalgia. Previously described as the most difficult years for communities, they were presented as a time when parents controlled their children and paramilitaries ‘policed, for the most part, with compassion’ (Community member). The reality was that children and young people had been kept indoors, their use of public space and free-time curtailed to ensure their safety. Further, paramilitary regulation had created an undercurrent of fear - inhibiting young people's opportunities to 'hang about' in their local communities.

Adults across the communities were concerned that effective controls on anti-social or criminal behaviour had diminished, leaving a 'policing vacuum'. Likewise, commenting on the increasing availability of drugs within communities, some young people suggested that 'Paramilitaries were good for communities. They kept the riff-raff out. They'd stop gangs' (Young people, aged 16-21). Others struggled with the moral contradiction raised by use of extreme physical punishment to protect the community against harmful behaviour as young people remained at the sharp end of community-based regulation and control. ${ }^{4}$

The police were either unwilling to intervene or unwelcome in communities where a history of mistrust existed as a result of personal, family or community experiences. Among some community members, there was resentment towards the previous 'protectors' who had withdrawn their control while actively discouraging co-operation with the police. Considering this to be a consequence of external political agreements without community consultation, community members felt they had been left unsupported to deal with unacceptable or anti-social behaviour by young people:

'The police are not there and the paramilitaries will do nothin' about it. Young people have no fear so they behave as they like.' (Community member)

\footnotetext{
${ }^{4}$ Between January 2008 and December 2010, 47 per cent of the 272 recorded 'casualties as a result of paramilitary style attacks' were carried out against young people aged under 25, including 91 assaults and 38 shootings (PSNI 2011, 4).
} 
'If something happens now, you feel you have nowhere to go.' (Community member)

Given their recent history of differential policing, the expectation that Nationalist/ Republican communities would willingly accept, trust and work with the police was unrealistic. Thus a 'policing void' had consolidated:

'There is much confusion among people in these communities - they can't trust the police and they can't trust the men in their own communities. So they are left in a noman’s land.' (Community worker)

Former 'protectors' were also less visible and active in Unionist/ Loyalist communities. There was a reticence to involve the police in local issues for fear of reprisal: 'the fear factor is a legacy of the conflict' (Community worker). Some expressed the view that the powers of the 'new' police force in Northern Ireland, re-branded as the Police Service of Northern Ireland (PSNI - previously the Royal Ulster Constabulary) under the terms of the Good Friday/ Belfast Agreement, had been weakened considerably by compliance with human rights:

'Human rights have taken over. The police regulated in the past but can't do it now, they can’t break up a group of lads [standing on the street].' (Community member)

These views of policing were rooted in contrasting experiences and perceptions between communities. While many in Catholic/ Nationalist/ Republican communities believed the police continued to represent the interests of the Protestant/ Unionist/ Loyalist communities, many in the latter considered that the discourse of human rights had given advantage to the former.

Partly because of increased visibility, and partly because of how some dealt with change - manifested in violence towards others or themselves - young people were the focus of adult concern. There was a sense that frustrations were simmering and could boil over at any time: 'Something will ignite it ... and it will erupt' (Community member). In some communities there was a feeling of despondency: 'everyone washes their hands of these young people - there is a paralysis in dealing with young people' (Community worker). 
While community members were united previously by fear and rejection of the 'common enemy', the outsider, adults across the six communities shared fear of, and hostility towards, 'the enemy within' - young people from their neighbourhoods.

\section{Identities in transition}

Concerns were also expressed about sectarian and territorial attitudes or behaviour of children and young people. Older residents, in particular, found this difficult to understand given the 'new' context of 'peace' and the fact that young people had 'never lived through the Troubles’ (Community member). Many young people, however, had been bereaved through the Conflict, witnessed or experienced sectarian violence, been the victims of paramilitary warnings or beatings and lived in heavily militarised communities.

Research in Northern Ireland demonstrates consistently that children and young people learn about their own and the 'other community' through the inter-generational transmission of messages passed down by family and community members (Ewart and Schubotz 2004; McGrellis 2004; Roche 2008). Lack of contact with the 'other community' consolidates ‘difference’ over time. The ‘downside’ of strong communities - 'homogenous ties of solidarity between "people like us”' (McGrellis 2004, 4) - leads to a lack of understanding, mistrust and hostility towards 'the other'. Yet, an understanding of 'difference' is necessary to negotiate safety in a divided society. Symbolic markers of identity - flags, murals, street names, modes of dress (e.g. soccer and Gaelic football shirts representing teams aligned with particular communities) - identify areas or social situations of safety and belonging as well as the boundaries of risk.

Although often unclear about how their understanding developed, the children and young people interviewed knew the markers and cues used to identify their own and 'the other' cultural and political communities. They understood separatism and 'difference', speaking about the impact on their lives. Few, however, had a deep understanding of 'their' culture and how it differed from the 'other' culture. Separation was normalised in their lives through a simplistic notion of inherent difference between 'Catholics' and 'Protestants':

'It’s just a general dislike for each other.' (Young people, aged 15-19 years) 
Researcher: 'So why are the Catholics and Protestants fightin'?'

YP: 'If you're a Protestant, you're a Protestant, if you're a Catholic [pause]...'

(Young people, aged 13-16)

Notions of 'difference' created fear and were derived in preconceived, often stereotypical, beliefs about the 'other community':

'Like, see, before you even meet them [Catholics] like they're always gonna have a different opinion of like what you are ... a long time ago, before I met them, I would think I would hate them ... and I would always argue with them. But then, when you meet up, they're really dead on ...' (Children and young people, aged 10-13 years)

While contact through cross-community schemes and community relations programmes softened attitudes, children and young people returned to their single identity communities, schools and social activities unable to disclose these experiences. Meeting 'others' often changed assumptions about those they had met on programmes, but this did not extend to general attitudes regarding the 'other' community (McAlister, Scraton, and Haydon 2009, 99102):

Young Person 1: 'But there are some dead on Catholics.'

Young Person 2: 'Oh aye there is.'

Young Person 5: 'But there’s not a lot like.’

(Young people, aged 13-15)

Playing cross-community soccer or experiencing cross-community residentials provided opportunities for young people to share experiences. However, they rarely explored issues of cultural identity, similarity and difference. These findings relate to work on the 'contact hypothesis’ (Allport 1954 in Brewer 1999) which proposes the significance of intercommunity contact in mitigating negative attitudes towards 'the other community'. However, they also demonstrate that impact depends on the nature and duration of such contact and this cannot be decontextualised from young people's everyday lives (see Devine 2013; Bell 2012; Bell, Jarman and Harvey 2010). 
In the research, young people reflected on where they had learned about their own and the 'other community'. For some, the relevance of the recent past was evident in their experiences of the present: stories passed down in communities and families, remembered through murals, commemorations and memorial events acknowledge pain and injustice. They also socialise the next generation into their understanding and interpretation of the Conflict and its impact on families and local communities. Thus, cultural identities, social and political beliefs are reproduced:

'At the end of the day we're goin' by what our grannies and grandads are tellin' us and they're puttin' it on the news and they're makin' films about it. And what are we supposed to think when they make a film about Bloody Sunday or they make a film about the bombin's and what not? ... so of course young one’s are goin' to fight back - “Oh you did this to my one” - you know, war stories you could say it is.' (Young person, aged 21)

Remembering the past, while ensuring that pain and suffering is not exacerbated or blame and resentment is not perpetuated, is a significant challenge in the process of transition from conflict. A further challenge is to ensure that one community does not consider it has been penalised or disadvantaged during the processes of truth recovery, equality promotion and individual/ institutional accountability. As Cohen $(2010,109)$ notes, feeling 'under threat... is a ready means of mobilizing collectivity ... one often finds in such communities the proposal of change being regarded ominously, as if change inevitably means loss’.

In the research there was a strong feeling among the Unionists/ Loyalists interviewed that the outworkings of the Peace Agreement disproportionately had benefited Nationalist/ Republican communities: 'it is all about keeping Sinn Fein happy ... people feel the DUP [Democratic Unionist Party] has sold them out ...' (Community member). The re-branding of the police force, the devolution of policing and criminal justice, the establishment of a Parades Commission, the introduction of a flags protocol and, most recently, the removal of the union flag from Belfast City Hall other than on designated days, have been perceived and represented as an attack on British identity and a diminishing of Unionist/ Loyalist culture. ${ }^{5}$

\footnotetext{
${ }^{5}$ Parades and flags are symbolic expressions of community and cultural identity. Given that identities are oppositional, one community expressing their identity through such rituals can be seen by the 'other community' as a threat to their identity.
} 
The response within Loyalism has been to reaffirm its 'British’ cultural identity, culminating in acts of collective violence directed towards the police and Nationalist/ Republican communities.

This is the context within which children and young people living in communities profoundly affected by the Conflict have developed their political consciousness. In learning about exclusive and oppositional identities, the meaning and ownership of physical territory and stories of past wrong-doing, it is unsurprising that young people within these communities continue to defend what they consider to be their local space; openly and aggressively displaying sectarianism and their mistrust of the 'other'.

Those who work closely with children and young people recognise these tensions. Within the research, many considered that young people, young men in particular, were confused by the mixed messages generated by the transition from conflict. Having been socialised into strong cultural identities - which they were expected to defend, sometimes through violence - past expectations had been reversed. Previously accepted behaviour and/or responses were no longer tolerated:

'There are confusing messages for young people. Now adults are saying “Don’t do that [support 'the cause']”, when in the past they were told to do it.' (Community worker)

Working class young men with strong cultural and community identities experienced a collective sense of loss - there were no jobs, education was not valued and there were few alternative prospects (see also Lloyd 2009). This was echoed across the communities:

'It was always in the heads of these young men, “We're tough, we're from [name of area]”. They had an image, now they're not allowed that. It has been taken away and nothing has replaced it. They were something in the past and now they're not.' (Community worker)

Young men's identity and place within their communities as protectors, defenders of space, were no longer unambiguous. Many were 'disillusioned and alienated from community life' (Community worker), lacking self-worth and hope. Some responded by asserting their 
masculinity and sectarianism to defend a culture they believed was under threat. Others internalised their pain and confusion, manifested in alcohol abuse and, in extreme cases, taking their own lives.

Young men from both communities expressed the importance of their culture for their sense of self:

'Protestant - it's everything, more or less everything - the way you've been brought up, everything you believe in' (Young people, aged 16-21)

'Everybody needs culture, everybody needs something to believe in ...' (Young people, aged 16-17)

Capitalising on young people's need for 'something to believe in', powerful adults fuelled fears about a loss or dilution of cultural identity, promoting discontentment with the Agreement. The growing tension was most evident in Unionist/ Loyalist communities:

'It might get better than it is but it could get far worse. Some of what you see is only the beginning. Catholics down here get everything and that's not right.' (Young people, aged 16-21).

Community representatives described how ‘local hard men’ politicised young people through glorifying the past and propagating the notion that their politicians had 'sold out'. Labelled locally as 'armchair paramilitaries', they were rarely visible but preying on young people; feeding their fears and emphasising their vulnerabilities. In situations where young people's role and identity were uncertain, where there were few opportunities, they were considered 'easy to drag in and give a focus in their lives' (Community worker). The continuing recruitment of children and young people into violent sectarianism, often in the guise of celebrating cultural tradition or protecting cultural identity, remains a crucial issue inhibition in communities working towards positive cross-community relations. 


\section{Children and young people within communities in transition}

Analysis of the community representatives' often contradictory views regarding the position of children and young people reveals a generation pulled in opposing directions. First, by politicians who expect a shift from use of violence to achieve objectives towards politically negotiated solutions. Second, by community 'hardliners' who 'keep the pot boiling’(Community worker). Some recognised that communities were unprepared for change and consequently 'nothing was ever explained to young people - policing was never explained, change was never explained' (Community worker). While some young people struggled to retain or reclaim an identity and sense of belonging, in so doing they had become feared and shunned within their neighbourhoods.

Although many adults considered children and young people to be disconnected from their communities, this was challenged by young people. They demonstrated strong attachments to their communities and their concerns were similar to those of adults. Yet they felt distrusted, disrespected and disliked within their neighbourhoods, considered a problem from which the community wished to be free: 'People aren't bothered with us, they just want us out of their area ... but it's our area as well' (Young people, aged 16-21). Rather than being places of inclusion and belonging, for some young people their communities were places of exclusion.

There was recognition that young people should be 'better connected to community life' (Community worker). Beyond youth work provision, however, few formal efforts were made to attain this objective. Consistent with the separation of the two main ethno-national groups, this age-related separatism failed to challenge negative preconceptions and stereotypes. No Resident or Community Forums included child or youth representatives nor, according to children and young people, were they included in community-based programmes or decision-making. This compounded the belief that their views and experiences were of no significance to the wider community:

'Most of them [adults] just aren't interested in what young people want or think. They never ask.' (Young people, aged 19-20) 
'If one of us went in [to a community meeting], they wouldn't respect our views. But if we sent an older person in, then they'd respect them.' (Young people, aged 13-15)

In particular, children and young people voiced annoyance about their exclusion from community meetings where, ironically, they were regularly the focus of attention. While individuals from outside the community, such as councillors and police officers, were invited, local children and young people were excluded. Expressing their concern, young people commented:

YP1: 'They talk about the young ones but you don't get to give your side.'

YP2: 'It's not fair - they have meetings about us, but we're not allowed to be there to defend ourselves.'

Researcher: 'How do you feel about that?'

YP1: 'Powerless.'

YP2: 'They have a say, we don’t.'

(Young people, aged 15-19)

YP1: 'It's ok for them. Adults speak for themselves and can speak for themselves. They have their community meetings and we're left out.'

YP2: 'Yeah, how can you get a word in if they have private meetings?'

Researcher: 'How do you feel when that happens?'

YP1: 'You're made to feel excluded. Younger ones need to be given a chance.'

(Young people, aged 16-21)

Exclusion from community decision-making processes was instructive to young people, demonstrating that their views were inconsequential, that adults were unwilling to listen, and that they were not valued as community members.

The negative behaviour of some young people led to their collective demonisation within their neighbourhoods. They were labelled and defined as a 'problem', separate from rather than integral to the community. There were calls for more authoritarian responses to what was labelled 'unacceptable' or 'anti-social' behaviour. Yet there was some understanding of the difficulties faced by young people in the transition from conflict and towards adulthood in communities offering limited opportunities. Ironically, experiences of 
marginalisation had led some young people to engage in the very anti-social activities that caused concern to adults.

\section{Conclusion}

While the external perception of Northern Ireland is a society that has emerged successfully from three decades of war, the impact of the Conflict continues. The broadly proclaimed peace dividend was not evident in the views of children, young people, community members and workers who participated in the research. Frustration, anger and resentment were voiced regarding the rhetoric of 'peace' and claims for 'progress'. The research found that the six economically disadvantaged communities deeply affected by the Conflict were attempting to address its legacy with inadequate resources.

In their narratives of community life, three broad tensions and contradictions emerged: increased feelings of insecurity despite a decline in violence; adult concerns about the sometimes sectarian and violent behaviour of young people while failing to consider its context; strong community and cultural identities among young people yet a tendency for them to be marginalised and demonised. Young people who occupied social spaces previously denied because of fears about their safety or paramilitary regulation of their behaviour were condemned as 'anti-social'. Their presence on the streets was often perceived as threatening community stability and instilling fear in older people. This encouraged further demonisation, alienating young people from their communities.

Young people and community workers noted that many young people were confused about their cultural identity. Working class young men retained a strong cultural and community identity yet they experienced a collective sense of loss. Erosion of work and social opportunities, coupled with perceived threats to their cultural identity, particularly in Protestant/ Unionist/ Loyalist communities, brought angry responses. Some young people asserted their sectarian identity to defend a way of life and a culture they believed was being eroded. This was exacerbated by a commonly-held belief that their exclusion was deliberate, manifested in failure to invite their participation in community decision-making processes.

While young people resented what they viewed as discriminatory policing, through which they were targeted on the streets solely because of age, community members raised 
concern about a 'policing vacuum' and 'withdrawal' of paramilitary regulation of young people's challenging behaviour. The research revealed, however, that the behind-the-scenes presence of former paramilitaries, and the emergence of quasi-paramilitaries, generated a climate in which violence could occur at any time. This was fuelled by the consolidation of discontent with the peace process.

The critical research ensured that participants could discuss issues in their own terms, explain their views or behaviours and key influences. This revealed a nuanced account of segregation and sectarianism in contemporary Northern Ireland. Despite claims for progress towards cross-community association, the lives of children and young people within the six communities were defined by division. Schooling, housing and leisure facilities remained deeply segregated, ensuring inter-community and territorial hostility. Sectarian clashes provided the opportunity to assert and display cultural identity, often cloaked as a response to perceived inequalities. It is an irony that some adults who condemned the anti-social behaviour of young people within their community actively encouraged violence and aggression when this was directed outside the community against the 'other'.

Acknowledgements: The research from which this paper is based was a partnership project between Queen's University Belfast, Save the Children Northern Ireland and The Prince's Trust. We thank the children, young people and adults within the communities for giving generously of their time and experiences.

\section{References}

Barrett, M. and Oppenheimer, L. 2011. “Findings, theories and methods in the study of children's national identifications and national attitudes.” European Journal of Developmental Psychology 8 (1): $5-24$.

Bell, J. 2012 Young People and the Interfaces. Belfast: Community Relations Council

Bell, J., Jarman, N. and Harvey, B. 2010 Beyond Belfast. Contested Spaces in Urban, Rural and Cross Border Settings. Belfast: Community Relations Council 
Boal, F. 1982. "Segregating and Mixing: Space and Residence in Belfast.” In Integration and Division: Geographical Perspectives on the Northern Ireland Problem, edited by F. Boal and D. Nelville. London, Academic Press.

Brewer, M. 1999. “The Psychology of Prejudice: Ingroup Love or Outgroup Hate?” Journal of Social Issues 55 (3): 429-444.

Brown, P. 2002. "Peace but no love as Northern Ireland divide grows ever wider”. The Guardian. 4 January 2002

Byrne, J., M. Conway, and M. Ostermeyer 2005. Young People's Attitudes and Experiences of Policing, Violence and Community Safety in North Belfast. Belfast: Northern Ireland Policing Board.

Cairns, E. 1987. Caught in the Ceasefire: Children and the Northern Ireland Conflict. Belfast: Appletree Press.

Cattell, V. 2001. "Poor people, poor places, and poor health: the mediating role of social networks and social capital.” Social Science and Medicine 52: 1501-1516.

Cohen, A. 2010. The Symbolic Construction of Community. Oxon: Routledge.

Connolly, P. and J. Healy 2004. Children and Conflict in Northern Ireland: The Experiences and Perspectives of 3-11 Year Olds. Belfast: OFMDFM.

DENI (Department of Education Northern Ireland) 2008. Enrolments at schools and in funded preschool education in Northern Ireland 2007-08 Statistical Press release, DENI, 26 February.

Devine, P. 2013. Into the mix. ARK Research Update

83. www.ark.ac.uk/publications/updates/update83.pdf

Devine, P. and Robinson, G. 2012. No more ‘us and them' for 16 year olds. ARK Research Update 79. www.ark.ac.uk/publications/updates/update79.pdf

Dixon 2004 
Ewart, S. and D. Schubotz 2004. Voices behind the Statistics: Young People’s Views on Sectarianism in Northern Ireland. London: NCB.

Fay, M., M. Morrissey, and M-T Smyth 1998. Mapping troubles-related deaths in Northern Ireland 1969-1998. Derry/Londonderry: INCORE (2nd edition).

Gallagher, E. and Cairns, E. 2011. "National identity and in-group/ out-group attitudes: Catholic and Protestant children in Northern Ireland.” European Journal of Developmental Psychology 8 (1): 5873.

Hamilton, J., U. Hansson, J. Bell, and S. Toucas 2008. Segregated Lives: Social Divisions, Sectarianism and Everyday Life in Northern Ireland. Belfast: Institute of Conflict Research.

Hansson, U. 2005. Troubled Youth? Young People, Violence and Disorder in Northern Ireland. Belfast: Institute for Conflict Research.

Hillyard, P., G. Kelly, E. McLaughlin, D. Patsios, and M. Tomlinson 2003. Bare Necessities: Poverty and Social Exclusion in Northern Ireland. Belfast : Democratic Dialogue.

Hillyard, P., B. Rolston, and M. Tomlinson 2005. Poverty and Conflict in Ireland: An International Perspective. Dublin: Institute of Public Administration/ Combat Poverty Agency.

Horgan, G. 2011. “The Making of an Outsider: Growing Up in Poverty in Northern Ireland.” Youth and Society 43 (2): 453-467.

Jarman, N. 2005. No Longer a Problem? Sectarian Violence in Northern Ireland. Belfast: Institute for Conflict Research.

Kilkelly, U., R. Kilpatrick, L. Lundy, L. Moore, P. Scraton, C. Davey, C. Dwyer and S. McAlister 2004. Children's Rights in Northern Ireland. Belfast: Northern Ireland Commissioner for Children and Young People.

Knox, C. 2002. “'See No Evil, Hear No Evil’: Insidious Paramilitary Violence in Northern Ireland.” British Journal of Criminology 42: 164-185. 
Leonard, M. 2004. “Bonding and bridging social capital: reflections from Belfast.” Sociology, 38 (5): 927-944.

Lloyd, T. 2009. Stuck in the middle: some young men's attitudes and experiences of violence, conflict and safety. Belfast: University of Ulster.

MacGinty, R., O. Muldoon, and N. Ferguson 2007. "No War, No Peace: Northern Ireland after the Agreement.” Political Psychology 28 (1): 1-11.

McAlister, S., P. Scraton, and D. Haydon 2011. “Place, territory and young people's identity in the 'new' Northern Ireland”. In Youth in Crisis? Gangs, territoriality and violence, edited by B. Goldson, 89-109, London: Routledge.

McAlister, S., P. Scraton, and D. Haydon 2009. Childhood in Transition: Experiencing Marginalisation and Conflict in Northern Ireland. Belfast: Queen's University, Save the Children and Prince’s Trust.

McDonald, H. 2009. “Belfast’s ‘Peace Walls’ Treble after Ceasefires.” The Guardian, July 28. Available from:

http://www.guardian.co.uk/uk/2009/jul/28/peace-walls-belfast-ceasefire

McGrellis, S. 2004. Pushing the Boundaries in Northern Ireland: Young People, Violence and Sectarianism. London: London South Bank University.

Murtagh, B. 2002. The Politics of Territory: Policing and Segregation in Northern Ireland. Hampshire: Palgrave Macmillan.

Murtagh, B. 2008. New Spaces and Old in 'Post-Conflict' Belfast. Divided Cities/ Contested States Working Paper, No. 5.

www.conflictincities.org/PDFs/WorkingPaper5_10.9.08.pdf

Nolan, P. 2012. Peace Monitoring Report Number One. Belfast: Community Relations Council. 
O`Dowd, L. and M. Komarova 2009. Regeneration in a Contested City: A Belfast Case Study.

Divided Cities/ Contested States Working Paper, No.10

www.conflictincities.org/PDFs/WorkingPaper10 14.4.10.pdf

Police Service of Northern Ireland (PSNI) 2011. Paramilitary Style Incidents. Freedom of Information Request F-2011-00341.

Roche, R. 2008. Sectarianism and Segregation in Urban Northern Ireland: Northern Irish Youth Post-Agreement. A Report on the Facts, Fears and Feelings Project. Belfast: Queen's University.

Save the Children 2007. A 2020 Vision: ending child poverty in Northern Ireland. Annual Child Poverty Report 2007. Belfast: Save the Children.

Shirlow, P. 2003. "Ethno-sectarianism and the reproduction of fear in Belfast.” Capital and Class, 80: 77-93.

Shirlow, P. and B. Murtagh 2006. Belfast: Segregation, Violence and the City. London: Pluto Press.

Shuttleworth, I. and C. Lloyd 2008. “Are Northern Ireland communities dividing? Evidence from geographically consistent Census of Population data 1971-2001.” Environment and Planning A 41 (11): 213-229.

Smyth, M. 1998. Half the Battle: Understanding the Effects of the Troubles on Children and Young People in Northern Ireland Derry/ Londonderry:

INCORE. http://cain.ulst.ac.uk/issues/violence/cts/smyth.htm

?Smyth 2000 - on p5

Smyth, M. 2004. "The Process of Demilitarisation and the Reversibility of the Peace Process in Northern Ireland.” Terrorism and Political Violence 16(3): 544-566.

Smyth, M., M-T Fay, E. Brough, and J. Hamilton 2004. The Impact of Political Conflict on Children in Northern Ireland. Belfast: Institute of Conflict Research. 
Tajfel, H. and Turner, J. C. 1986. “The Social Identity Theory of Intergroup Behavior.” In Psychology of Intergroup Relationsedited by S. Worchel and W. Austin. Chicago, Nelson Hall.

Trew, K. 2004. “Children and Socio-Cultural Divisions in Northern Ireland.” Journal of Social Issues 60 (3): 507-522.

Trew, K. 1992. “Social Psychological Research on the Conflict.” The Psychologist, 5: 342-344.

Suttles, G. 1972. The Social Construction of Communities. Chicago: University of Chicago Press.

White, R. and J. Wyn 2008. Youth and Society. Victoria: Oxford University Press. 